\title{
Climate Change Variability and Mitigating Measures by Rural Dwellers: the Perception of Arable Farmers
}

\author{
C. O. Albert ${ }^{1} \&$ I. A. Okidim ${ }^{1}$ \\ ${ }^{1}$ Department of Agricultural and Applied Economics/Extension, Rivers State University of Science and \\ Technology, Port Harcourt, Nigeria \\ Correspondence: I. A. Okidim, Department of Agricultural and Applied Economics/Extension, Rivers State \\ University of Science and Technology, Port Harcourt, Nigeria. E-mail: carobinedo@yahoo.com
}

\author{
Received: August 26, 2013 Accepted: October 8, 2013 Online Published: December 15, 2013 \\ doi:10.5539/jas.v6n1p167 URL: http://dx.doi.org/10.5539/jas.v6n1p167
}

\begin{abstract}
The study investigated the perception of arable crop farmers on climate change variability and the mitigating measures taken by them. It was carried out in Ahoada-East Local Government Area of Rivers State. Interview schedule was used to elicit information from the respondents. Proportionate sampling technique was employed to select ninety arable crop farmers from the study area. Data collected were analyzed using descriptive statistics and simple Ordinary Least Square (OLS) regression at 0.05 significant level was used to test the hypothesis. The findings from the study revealed that female dominated arable crop, and have been farming for the past 12 years. A higher percentage of the arable farmers were aware of climate change and were of the opinion that climate change was caused by bush burning, desertification, clearing of land for agriculture and act of gods. The effects of climate change on arable crops were poor/low yield, increased incidence of pest and diseases and induce spoilage of crops very fast. The mitigating strategies adopted by arable farmers to reduce the effects of climate change on their crops were, early harvesting of crops and mixed farming. Excessive rainfall and sunshine which were some of the signs of climate change affect arable crops when planted, which had led to low yield.
\end{abstract}

Keywords: climate change variability, effects, mitigating measures

\section{Introduction}

Rural farmers in Nigeria had at various times, expressed concerns on the potential effects of climate change on agricultural productivity (Egbule, 2010). The effect of rainfall on crop is a function of the temperature values which affect evaporation and transpiration (Rudolf \& Harmann, 2009). According to Smith and Skinnes (2002) climate plays dominant role in agriculture, having a direct impact on the productivity of physical production factors, for example, the oil moisture and fertility. Butt et al. (2005) assert that farmers predict future economic loses and increased risk of hunger due to climate change. It seems clear that the combination of high climate viability, poor infrastructures, economic poverty, drought, excess rainfall, reduced crop yields, low productivity and a range of other problems associated with climate change. Farmers' variability will constitute important challenges in African countries particularly in Rivers State (Chang et al., 2002). Famers in Rivers State are experiencing climate change even though they have not considered its deeper implications. This is evident in the late or early commencement of rainfall and drying up of streams. Farmers in the rural parts of Rivers State have to a large extent, been able to develop their livelihood strategies in a way which enables them to constantly cope with and adapt to an erratic change in crop production (Apata \& Adeola, 2009).

Arable crops include plants (cereal, fruit and vegetable) that are on ploughed land. Cereals such as wheat, maize, barley, and oil seed are arable crops. Other arable crops are in the classes of fruits, vegetables and ornamentals. Olei et al. (2009) defined arable crops as crops which are cultivated on ploughed land, and used for food, fuel, feed, fiber and reclamation. They are annual crops and so harvested yearly.

The long term alteration in global weather patterns that is climate change in the form of increase in temperature and storm activities have resulted to changes in crop production. More than $80 \%$ of rural dwellers are arable farmers. Farmers are responsible for half of the world's food production and in most developing countries; they produce between 60 and 80 percent of the food (Simm \& Reid, 2005). Farmers have always responded to climate change with respect to their corps in the areas of planting and other cultural measures. Detrimental effect of climate change can be felt in short term through natural hazards, such as floods, sea rise, and drought. Until now the appropriate 
true for planting arable crops like yam, cassava, maize, pumpkin flute in Ahoada-East, Rivers State is in early February to late March when the first rain must have fallen. This is to make the soil soft and enhance its fertility. Today, the rural dwellers do not know when to plant because of the increscent rainfall that begin from late January, Farmers do plant whenever the weather is fair and sometimes after planting, when it rains it is so heavy that the land get flooded.

In addressing this problem, it is necessary to find answers to the following research questions. Are arable crop farmers aware that there is climate change? If they are, what are their views or perception on climate change and the causes of this climate change? What is the effect of the climate change on their arable crops? What measures can be taken to correct or advert the effect of climate change on their crops?

\section{Methodology}

The study was carried out in Ahoada-East, one of the local government areas that made up the 23 local government areas in Rivers State of Nigeria. Ahoada-East has a tropical rainforest with two seasons - wet and dry. The major occupation of the people of Ahoada-East is predominately farming, fishing and to a lesser extent, trading. There are 3 clans (Akoh, Upata and Ahoada) in Ahoada-East LGA that comprises 28 communities. Akoh has 8 communities, Upata 10 communities and Ahoada 10 communities. Three communities were randomly selected from each clan giving a total of 9 communities. Proportionate sampling technique was employed to selected 10 farmers from each of the selected communities. This is to ensure an equal number of respondents from each of the selected communities. Structured questionnaire for literate respondents and interview schedule for the illiterates were used as the research instrument to elicit information from the farmers. Data collected were subjected to descriptive statistics. A four point lekert - type scale with options: A great cause (4); a cause (3) less cause (2) and not a cause (1) was used to determine the cause of climate change; very effective (4); effective (3); less effective (2) and not effective (1) was used to examined the effects of climate change on arable crops and to a very great extent (4); great extent (3); less extent (2) and no extent (1) was used to ascertained the mitigating measures to reduce the effect of climate change on arable crop farmers. The values were added to give 10 which were further divided by 4 , to give a mean value of 2.5. The mean value was used to judge the farmers perception on the causes, effects and mitigating steps of climate change on arable crops. The hypothesis which is there is no significant relationship between climate change and arable crop production was tested using simple Ordinary Least Square (OLS) regression at 0.05 significant level. The model was: $\mathrm{Y}=\mathrm{ax}_{1}+\mathrm{x}_{2}+\mathrm{x}_{3}+\mathrm{x}_{4}+\mathrm{x}_{5}+\mathrm{x}_{6}+----\mathrm{e}$

$\mathrm{Y}$ is the independent variable (climate change)

$$
\begin{array}{ll}
\mathrm{X}_{1}=\mathrm{f}(\mathrm{Y}) \text {---- } & =\text { cassava; } \\
\mathrm{X}_{2}=\mathrm{f}(\mathrm{Y}) \text {---- } & =\text { maize; } \\
\mathrm{X}_{3}=\mathrm{f}(\mathrm{Y}) \text {---- } & =\text { yam; } \\
\mathrm{X}_{4}=\mathrm{f}(\mathrm{Y}) \text {---- } & =\text { pumpkins; } \\
\mathrm{X}_{5}=\mathrm{f}(\mathrm{Y}) \text {---- } & =\text { tomatoes; } \\
\mathrm{X}_{6}=\mathrm{f}(\mathrm{Y}) \text {---- } & =\text { okra; } \\
\mathrm{X}_{7}=\mathrm{f}(\mathrm{Y}) \text {----- } & =\text { pepper; } \\
\mathrm{e} & =\text { error them. }
\end{array}
$$

\section{Results and Discussion}

\subsection{Extent of Climate Change Awareness by Arable Farmers}

Data in Figure 1 show that a great proportion of the respondents (81.4\%) were aware of climate change while18.6\% of the respondents were ignorant. From the data in Figure1, $81.4 \%$ claimed that change in drought, wind, humidity and rain fall was an indication that the climate condition have changed. The high level of awareness recorded by the respondents could mean that effect of climate change is very serious on them. The evidence as pointed by the respondents, are true of evidence recorded globally for climate change (Baidya, Shrestha, \& Shiekh, 2008; Khanal, 2009; Swift et al., 2002; Rosegrant, Nelson, \& Robertson, 2009). This finding is in contrast with the study conducted in Niger Delta of Nigeria, where a greater proportion of the respondents claimed to be unaware of climate change (Egbule, 2010) and agrees with that conducted in Imo State where a very good majority of the respondents were very much aware of climate change (Umunakwe, 2011). 


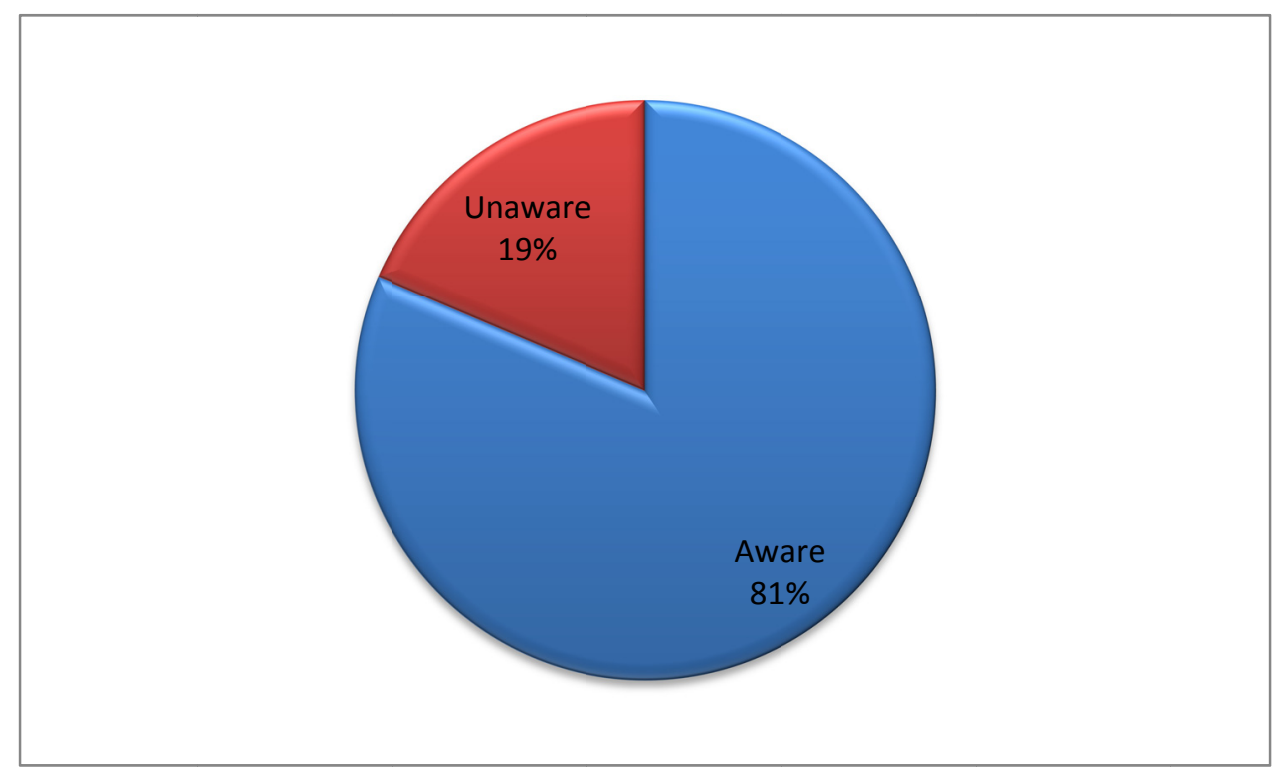

Figure 1. Pie chart showing percentage distribution of respondents on awareness of climate change

\subsection{Perceived Causes of Climate Change}

The result in Table 1 shows that arable crop farmers in Ahoada East LGA were of the opinion that climate change was caused by bushing burning $(M=2.5)$, desertification $(M=2.7)$, and act of gods $(m=3.0)$. From Table 1 , the high level of ignorance of these respondents over causes of climate change spells danger on the area particularly and the country in general. Their ignorance about the causes of climate change implies that they cannot effectively affect mitigation measures because what one mitigates, is what one knows. The findings of this study disagree with the study in Niger Delta of Nigeria, where majority of the respondents could identify the causes of climate change (Egbule, 2010).

Table 1. Mean distribution on the perceived causes of climate change by respondents

\begin{tabular}{llll}
\hline Causes & Total score & Mean (M) & Remarks \\
\hline Deforestation & 175 & 2.0 & Not a cause \\
Bush burning & 216 & 2.5 & Cause \\
Burning of fossil fuel & 175 & 2.0 & Not a cause \\
Use of agrochemical & 189 & 2.2 & Not a cause \\
Methane & 129 & 1.5 & Not a cause \\
Desertification & 233 & 2.7 & Cause \\
Biomass burning & 171 & 1.9 & Not a cause \\
Changes in sun energy output & 148 & 1.7 & Not a cause \\
Act of gods' & 261 & 3.0 & Cause \\
\hline
\end{tabular}

Source: Field survey, 2012. *Mean $= \pm 2.5$.

\subsection{Effect of Climate Change on Arable Crops}

Table 2 show the effect of climate change on arable crops. It was apparent that almost all the variables outlined for the respondents to choose were all possible effect of climate change on arable crop, apart from one which means score was below 2.5. (Increase in yield spoilage $m=1.5$ ). From the entries in Table 2, The result implies that poor/low yield, affects only crop quality negatively, affect both yield and quality negatively, increase poverty of farmers, changes the rain fall pattern, increase cost of production, increase in temperature, reduces the effect of fertilizer used and increase incidence of pest and disease were the effects of climate change on arable crops. This 
result agrees with those of Rose and Weight (2007), Schneider (2007) and Change (2002) that the effects of climate change were drought, excessive rain fall, raise in sea levels, and water scarcity among others.

Table 2. Mean distribution on the effect of climate change on arable corps

\begin{tabular}{llll}
\hline Effects & Total score & Mean (M) & Remarks \\
\hline Poor/low yield & 261 & 3.0 & Effect \\
Increase in yield spoilage & 129 & 1.5 & Not an effect \\
Affect only crop quality negatively & 228 & 3.3 & Effect \\
Affect both yield and quality negatively & 288 & 3.3 & Effect \\
Increase poverty of farmers & 244 & 2.8 & Effect \\
Changes the rain fall pattern & 288 & 3.3 & Effect \\
Increase cost of production & 244 & 2.8 & Effect \\
Increase in temperature & 296 & 3.4 & Effect \\
Reduces the effect of fertilizer used & 288 & 3.3 & Effect \\
Increase incidence of pest and diseases & 261 & 3.0 & Effect
\end{tabular}

Source: Field survey, 2012; *Mean $= \pm 2.5$.

\subsection{Mitigation to Reduce Effect of Climate Change}

The mitigating step taken by arable farmers in Ahoada-East LGA to reduce the effect of climate change on their crops as shown in Table 3 were farm irrigation $(m=3.0)$, early harvesting of crops $(m=3.2)$ and mixed farming $(\mathrm{m}=2.9)$. The result indicate that the farmers have less mitigating strategies and need to be exposed or taught new mitigating steps to apply in order to reduce the effects of climate change on their corps. The result disagrees with Nzeabide (2010), findings on mitigating steps taken by farmers on climate change in the Niger Delta region to include: prompt weeding, protection of water sheds and a forestation.

Table 3. Mitigating measures for climate change by arable farmers

\begin{tabular}{llll}
\hline Mitigating steps & Total score & Mean (M) & Remarks \\
\hline Farm irrigation & 266 & 3.0 & Mitigation step \\
Change in farming season & 172 & 2.0 & Not a mitigation step \\
Planting of trees & 143 & 1.7 & Not a mitigation step \\
Increase the size of mounds and ridges & 140 & 1.6 & Not a mitigation step \\
Early harvesting of crops & 276 & 3.2 & mitigation step \\
Crop diversification & 154 & 1.8 & Not a mitigation step \\
Prompt weeding & 204 & 2.3 & Not a mitigation step \\
Mixed farming & 246 & 2.9 & mitigation step \\
Migration from drier to water region & 171 & 1.9 & Not a mitigation step \\
Introduction of agro forestry system & 184 & 2.1 & Not a mitigation step \\
\hline
\end{tabular}

Source: Field survey, 2012; *Mean $= \pm 2.5$.

\subsection{Testing of Hypothesis}

The relationship between climate change $(\mathrm{Y})$ and cassava production $\left(\mathrm{X}_{1}\right)$ is negative, that is there was a significant negative relationship between cassava production and climate change $\mathrm{R}^{2}=72 \%$ showing that the coefficient of determination $\left(\mathrm{R}^{2}\right)$ explained the model that $72 \%$ of the variation in $\mathrm{X}_{1}$ was explained by $\mathrm{Y}$ only $28 \%$ was not explained. Also in the other simple regression model, $\mathrm{X}_{2}=-0.26, \mathrm{X}_{4}=-0.19, \mathrm{X}_{7}=-0.13$ and $\mathrm{X}_{6}=-0.27$ 
showing that $\left(\mathrm{X}_{2}=\right.$ maize $),\left(\mathrm{X}_{4}=\right.$ pumpkin $),\left(\mathrm{X}_{6}=\right.$ okra $)$ and $\left(\mathrm{X}_{7}=\right.$ pepper $)$ have a negative relationship with climate change. Only $\mathrm{X}_{3}=$ yam and $\mathrm{X}_{5}=$ tomato had a positive relationship with climate change $(\mathrm{Y})$.

Table 4. Results of multiple regressing in the relationship between climate change and arable crop production

\begin{tabular}{llll}
\hline Model & \multicolumn{2}{l}{ Unstandardized coefficients } & \\
\cline { 2 - 3 } & $\mathrm{B}$ & Standard error & Significant \\
\hline Constituted & 265.451 & 21.29 & .000 \\
$\mathrm{X}_{1}$ & -0.56 & 1.511 & 0.720 \\
$\mathrm{X}_{2}$ & -2.96 & 0.081 & 0.21 \\
$\mathrm{X}_{3}$ & 1.83 & 12.96 & $0.000^{*}$ \\
$\mathrm{X}_{4}$ & -2.16 & 8.16 & 1.32 \\
$\mathrm{X}_{5}$ & -2.9 & 8.96 & $0.000^{*}$ \\
$\mathrm{X}_{6}$ & -3.16 & 9.4 & $0.000^{*}$ \\
$\mathrm{X}_{7}$ & -1.49 & 7.92 & 0.740 \\
& 2.92 & 8.1 & $0.000^{*}$ \\
\hline
\end{tabular}

$* * *$ Significant, $* *$ Insignificant.

$\mathrm{X}=\mathrm{f}(\mathrm{Y})$

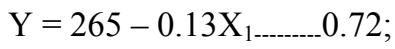

$\mathrm{Y}=2.65-0.26 \mathrm{X}_{2}-\mathrm{-}_{--2} 0.21$

$\mathrm{Y}=2.65-0.16 \mathrm{X}_{3}------0.08$;

$Y=2.65-0.19 X_{4}$-------12.96;

$\mathrm{Y}=2.65-0.26 \mathrm{X}_{5}$-------2.39;

$\mathrm{Y}=2.65-0,27 \mathrm{X}_{6}-------2.38$;

$* * * \mathrm{R}^{2}=0.72$;

$* * \mathrm{R}^{2}=0.21$.

The relationship between climate change and cassava production $\left(\mathrm{x}_{1}\right)$ is negative. Also, maize $\left(\mathrm{x}_{2}\right)$, pumpkin $\left(\mathrm{x}_{3}\right)$, okro $\left(\mathrm{x}_{6}\right)$, and pepper $\left(\mathrm{x}_{7}\right)$ showed negative relationship with climate change. This means that increase in climate change (hazardous weather condition or global warming) reduces yield of the above crops.

\section{Conclusion}

The arable farmers in the study area are aware that there is climate change but the knowledge on the causes of this climate change is very myopic and inadequate. The idea that climate change was punishment from the gods for man's wicked acts indicates their low knowledge on the causes of climate change. Also, the mitigating measures adopted by the farmers to reduce the effects of climate change on their crops were few. This shows how narrow they are in the knowledge of mitigating measures. It is therefore recommended that government and other development agencies like civil organization, NGO's and agricultural agent should intensify efforts to create awareness on the causes of climate change and the mitigating steps that can reduce the effects of climate change on crop production.

\section{References}

Apata, T. G., Samuel, K. D., \& Adeola, A. O. (2009). Analysis of climate change perception and adaptation among arable food crop farmers in South Western Nigeria. Paper presented at Ile Conference of International Association of agricultural economics. University of Ile Ife.

Butt, T. A., Mclan, B. A., Augenes, J., Dyke, P. T., \& Stuth, J. W. (2005). The Economic and Food Security Implications of climate change in Matia. Journal of climate change, 6(8), 355-378. http://dx.doi.org/10.1007/s10584-005-6014-0 
Chang, C. (2002). The Potential Impact of Climate Change on Taiwan's Agriculture. Agricultural Economics, 2(27), 51-64. http://dx.doi.org/10.1111/j.1574-0862.2002.tb00104.x

Olei, M., Cheikh, M., Anette, R., \& Awa, D. (2009). Farmers perceptions on climate change and agricultural strategies in Rural Sahei. Journal of Environment Men Agreement, 4(3), 804-816.

Rudolf, W., \& Harmann, W. (2009). Climate Risk and Farming Systems in Rural Cameroon. Institution of Development and Agricultural Economics. Germany: University of Hanover.

Simms, A., \& Reid, H. (2005). Africa-up in Smoke? Second report from the working group in climate change and development. London: New Economics foundation.

Smith, B., \& Skinnes, M. (2002). Adaptation options in Agriculture to Climate Change. A Hypnology, Mitigation and Adaptation Strategies for Global Change. African Journal of Agriculture and Resource Economics, 3(5), 78-82.

\section{Copyrights}

Copyright for this article is retained by the author(s), with first publication rights granted to the journal.

This is an open-access article distributed under the terms and conditions of the Creative Commons Attribution license (http://creativecommons.org/licenses/by/3.0/). 